\title{
Strategic alliance in technological development and innovation: Performance evaluation of co-creation between companies and their supply chain
}

Luiz Otavio Monteiro, Jose Rodrigues Faria Filho, Leandro Barreto, Alessandro Correa, Alberto Argolo, Jose Marcio Gramacho

Universidade Federal Fluminense (Brazil)

lomonteiro@gmail.com,fariasfilho@gmail.com,leandrombarreto@gmail.com,_alessandro.aa@@_dpf.gov.br,beto_argolo@yaboo.com.br. jmgramacho@gmail.com

\section{Abstract:}

Purpose The Brazilian oil and gas market presents a perspective of growth in the next decades. Considering this scenario, the increasing number of participants in this supply chain is foreseen to supply the demand of goods and services, especially in the technological development area. The paper intends to evaluate the collaborative development capacity and respective measurements of performance on these partnerships established between customer and suppliers, through qualitative research with a sample of Brazilian oil and gas market representative.

Design/methoddogy/approadr. This paper intends to verify if the co-creation performance is measured after an implementation, specific in a restricted industry. The methodology consists in a bibliographical research to support the study, and it also had a questionnaire sent to Brazilian companies that take part of the oil and natural gas industry supply chain, to analyze if the results of co-creation activities are measured by this group of companies, to verify its attractiveness to develop the co-creation usage or change the type of partnership with the market.

Findings: The misunderstanding of co-creation and technical partnership was noticed. The usage of teams working together from two or more organizations cannot be considered as a co- 
creation, because the relationship and obligations are different between these two ways of workgroup. But the companies of oil and gas industry, when questioned, were able to distinguish it, avoiding risks of incorrect results motivated by wrong interpretation of the paper content.

Research limitations/implications: As related in the paper, eight companies were invited to take part on the questionnaire about co-creation, but only 50\% answered it. The research should have a better result of this subject if it had been developed with more answers of Brazilian oil and gas industry companies.

Originality/value Even this kind of partnership is used in oil and natural gas industrial segment, the measurement isn't correct used. The value of this paper is to show that companies that are using co-creation could detect the best opportunities to apply it, due to the attractiveness that each situation can generate.

Keywords: partnership, performance, co-creation, investment, research and development

\section{Introduction}

The global oil and gas market has demonstrated potential of growth during the last few years. The Brazilian oil and gas market has the same perspective, with solid growth. As indicated for Petrobras (2011), amongst the total of US $\$ 224,7$ billion planned, US $\$ 213,5$ billion will be invested in national projects during the period 2011-2015.

As observed for Canellas (2007), the growth of the oil and gas sector in Brazil brings an increasing participation of this sector in the Brazilian economy. There is also a competition in exploration and oil production in Brazil, with new companies in Brazil, after an institutional change in 1997 that ended up the monopoly exerted by Petrobras.

In this scenario, it is necessary to develop a business model where an interaction occurs between the oil and gas companies' strategy of operations and its supply chain. This alliance also becomes important due to a fast and trustworthy reply to its demands and keeps its supply chain update with the technological evolution in its equipment and requested services.

For this, the development of a new supplier and a technological cooperation agreement becomes important to bring new qualified suppliers to the market. As indicated by Petrobras (2011), the development of suppliers is important to attend the demand with increasing local content requirements, help the development of innovative national companies.

This paper intends to approach the strategy used for national companies to establish relations with its suppliers, to support the technological development and innovations in its products and services. Specifically, it intends to demonstrate how the oil and gas national companies select 
the projects who will receive technical and financial support and how to measure the benefits of this practice.

\section{Analytical framework}

\subsection{Competitive strategies}

Research by Porter (1980) showed the use of strategic planning shows how a company can get benefits with the development of strategies, where practical activities are coordinated and directed aiming at a set of established goals. It allows a vision of the company as a whole in a market and foresees a scene of future evolution, trying to protect against competitors movements.

The level of competition in a market depends on the competitive external forces that influence the potential of return on the capital invested in the activities of each participant agent. The competitive strategy role is supply points to generate the best possible defense in the industry against the competitive forces that influence the market. The knowledge of strong and weak forces origin serves as an identification of strategically measures that must be adopted in accordance with the trends of the market.

\subsection{Business strategies}

According to Kotler (1994), many companies operate without formal plans. However, plans generated previously bring benefits. It stimulates to think about the future, with focus in its targets, coordinate the individual and collective efforts and create performance measures.

Research by Hunger (2002) showed the strategically management is the set of strategic decisions and actions that determine the performance of a corporation. In accordance with Porter (1980), the operating forces, as new competitors, rivalry between existing competitors, use of substitute products and influence of purchasers, reflect the idea that competition in an industry is not limited to the established participants.

According to Hunger (2002), the strategy development can be considered as a strategically planning, because it contains the mission, objectives, strategies and politics of a company. The initial step is the determination in which strategically way the company must be located, between the external opportunities and internal forces, while the market generates external threats $e$, in function of this, shows the identification of the company's internal weaknesses. This analysis does not restrict the identification of the company's advantages and abilities, but also opportunities that are not being used for the company or due to a planning fail or lack of resources.

\subsection{Innovation in the Brazilian oil industry}

The occurred institutional change in the decade of 90 , ending up the monopoly in oil and gas in Brazil, generated a different scenario in Brazilian oil industry. It obliged an increase on the number of suppliers in this market, to attend the increased demand due to new agents in this 
market. As a result, it required a raise on technological evolution to adapt the existing resources to the needs.

According to Petrobras (2011), the company foresees to duplicate its oil reserves up to 2020. The most important activities in new reserves are placed at recent Petrobras' discoveries in Pre-Salt.

The generation of innovation in this scenario, therefore, is a requirement to the agents who act in the oil and gas national industry. Previously on the monopoly's end, in research by Furtado (2003), the institutional arrangement guarantee convergence in the functions of an innovation system, where Petrobras financed, coordinated, executed and used the generated knowledge. However, this system had limitations to be used by an only agent.

The new model, beyond including the presence and control by a regulating agency (ANP), creates a fund that has an objective to stimulate the innovation in the oil and gas industry, the qualification of human resources and partnerships between companies and universities or research centers.

The research and development activities can be executed inside the company or in an alternative form (outsourcing). Research by Nelson (1992) showed that innovation in a national system depends basically on the interaction between the public area that is responsible for the generation and traffic of codified knowledge and the private area that produces knowledge. The innovation system of the Brazilian oil and gas industry is made by agents articulated between them. These agents consist of research institutions, government and companies in the sector, even the operators of the proper industry or the supply chain of equipment, services or outsourcing activities.

In accordance with UNICAMP (2010), Petrobras invested about US\$ 800 million in research and development in 2010, in contrast with 2001 year, when this sum did not reach US\$200 million. The company has its center of research in Rio de Janeiro dedicated to the activities of cooperation in research and development. According to ANP (2010), in concession contracts of high productivity and special participation, the companies must invest $1 \%$ of the produced value, in activities of research and development. A quota of this $1 \%$ needs to be destined to projects in cooperation with the universities and research centers.

\subsection{Cooperation and co-creation}

Research by Fischer and Varga (2002) suggests that a cooperation working net is a system based on systemic relations as result of interactions. Activities of this net involve the creation, combination, exchange, transformation, and exploitation of resources inside a formal or informal group. However, this is not yet a very popular practice in the management of the companies.

Although this, recent works had indicated that cooperation links between companies are positive and important for innovation. Fischer and Varga (2002) affirmed that relations 
between customers and suppliers are more important for innovation than the horizontal cooperative links (between company and competitors).

Freel and Harrison (2006) had noticed that the contribution with customers can assure that products will be drawn to adjust themselves to the most appropriate shape to the specifications of the customer and to the demands of the market. Moreover, the cooperation also facilitates to the chances of learning and synergy between the companies, and the exchange of information between the technical and management areas.

The innovation is an important tool for companies to create a potential of differentiation to the other competitors in its market. Ghemwhat (2007) affirms that the competitive advantage occur when the biggest difference between customer disposal to pay and the company productive costs happen.

Reseach by Luecke (2005) based on the theories of Schumpeter showed that exist incremental innovations, in an existing item, and radical innovations, that generates something new in an environment with diverse chances of growth and profitability, acoording to Kim and Mauborgne (2005).

The oil and gas industry requirements have an interaction with activities in its supply chain, and needs to have technical developments to adjust its plans of production and create a feedback environment between itself and its suppliers to avoid or minimize any operator's lack of necessity. In this question, this link can occur through the interaction between the customer and the company, in an activity named value co-creation (Prahalad \& Ramaswamy, 2004), which has a relation with the customer in the production process, interacting with the company in the search of value creation process.

\subsection{Measurement of Performance}

The performance of a company must be integrated with all the workflow sequence and become accessible in order to support production decisions, strategically and management decisions.

Research by Neely (1998) showed that a performance measurement system allows that the decisions are based on information, with an analysis of effectiveness made by compilation, classification, analysis, interpretation and dissemination of data.

Kaydos (1991) suggested that a system of performance measurement, to contribute effectively for the management, must inform the strategy and values of the organization, identify problems and opportunities, inform the processes and relation with goals of the organization, support the decision, define the responsibilities and create a performance index.

The data-collecting must be carried through in a structuralized form and based on compatible market situations with the index that wants to be evaluated. According to Nudurupati and Bititci (2000), performance measurement systems uses historical and static information, without update of its content, not being dynamic and sensitivity to show internal or external changes the company. 
Some authors had dedicated studies to show the importance of these performance measurement systems for an effective management. According to Neely, Mills, Platts, Richards, Gregory, Bourne et al. (2000), performance measurement systems project should consist of a project, implementation and use of the performance pointers.

Some analyses consider diverse methodologies to measure and update the performance index. Research by Kaplan and Norton (1992) considered the Balanced Scorecard methodology, where determined projections of performance pointers are guided by financial and not financial parameters.

\section{Methodology}

This paper intends to make an evaluation of co-creation performance using the qualitative research as the most appropriate form to lead the research.

Creswell and Clark (2006) suggested that the quantitative research is more appropriate for the theory test. The authors also suggest that the qualitative research is adjusted for the theory generation. The act of measure changeable pointers is a characteristic of the quantitative research. However, it is perfectly possible to find measurements whose alternative research does not believe that measures are a form to catch the reality.

The present work is based on an ample bibliographical research and intends to get evidences by a directed questionnaire sent to some companies of Petrobras supply chain. The interviews had been developed from a theoretical referential and the interview script was developed without necessarily imposing the vision of the interviewer to the interviewed company.

\section{Results}

For a better understanding of the reasons for which customers and suppliers are searching the improvement of its index of innovation, a research was carried through with some oil and gas companies. Eight companies with potential of participation in the research had been chosen, in virtue of well-known knowledge in the supply and development of new technologies. As a result, four companies participated of this evaluation effectively. All the participants had conditioned the authorization of data informed use with the secret of interviewed names or the company name.

The companies' investments in Research and Development (R\&D) are carried through by themselves or also in partnership. The majority of the investments in R\&D are carried through with their own budget and a small, but representative part is a partnership with its customers or supply chain.

The companies had pointed investment below $5 \%$, in the R\&D total amount in co-creation works. Although this low percentile in relation to the R\&D destined total for the companies, this is a substantial growth, with consequent increase in record patents number in Brazil.

The majority of the companies not only indicate partnership with the customers, but with its suppliers too. It is identified that all companies are linked to a major customer (Petrobras) that 
apply part of its investments in R\&D for partnerships, which intend a growth in the competitive advantage with other competitors. A major customer trusts a development of new equipment in another company because wants to buy it, what indicates that the development in partnership has great probability to turn a contract than other equipment developed by it.

The role of each company is defined in each project. Normally the customer indicates a technical team to follow the project in its partner, so that, in the ending of the development, the project can be $100 \%$ used by both.

All companies had informed that the selection criteria contain a possibility of future business. Amongst the companies, the historic of supplies was cited; hardly a company would trust an important project at the hands of a new company or with bad reputation. For all companies, the participation of operations management is important since the negotiations step until the project finishing.

As for the main R\&D projects in progress, that is being carried through in partnership, the companies had opted to not inform details. But they had reiterated that main projects are those that are being developed in set with the major customer, in the case Petrobras. $50 \%$ of the interviewed companies had not informed the value destined to invest in partnerships of $R \& D$. The remaining companies only confirmed the amount ( $5 \%$ of the total invested in R\&D).

There is not any criterion of results measurement of the companies exclusively of R\&D in partnerships. The perception is that results of the co-creation are being evaluated as positive per $100 \%$ of the companies in terms of fulfillment of the considered objectives at the beginning of the project.

Beyond not carrying through the internal measurement of the R\&D partnership projects results, all companies had not been able to inform if their customers have some performance measurement criterion in the co-creation. There is not a formal pointer currently to verify if the projects are reaching the expected results.

As main strong points of this co-creation analysis, the companies have intend to maturate its technical group, work in costs reduction, grow its competitive advantages and align its common objectives with the customer.

Amongst the weak points, the companies cited that copyright is not clearly about the ownership or property; specifications generally are imposed by the major customer, inhibiting the creative capacity of the company and the absence of commitment in sharing necessary resources to the development.

\section{Conclusions}

The Brazilian scenario of investments foreseen for the Petrobras stimulates the suppliers, beyond a consistent raise of purchases on these suppliers. The speed and the sum of investments foreseen for the next years impose a new method to attend the demand of new 
technologies. In this context, the co-creation has been seen as a viable alternative as much for customers and for suppliers.

The study demonstrated the great interest and necessity of oil and gas companies to invest in activities of co-creation and innovation, but also it evidenced the lack of standards and criteria for the measurement. Studies developed by Neely (1998) pointed a methodology based on the number of registered patents, but that not yet it comes being used in Brazil.

The benefit that comes of the application of the law of investments in R\&D can be perceived by the great customer's movement, mainly Petrobras, in bringing suppliers for the process of cocreation, because the company is not able to promote, by itself, the application of these resources in projects.

As challenges and impediments for these activities of R\&D developed in set, the establishment of the confidence between customer and supplier and the management of patents happened of these partnerships, beyond the possibility of the researches results in other products, even though competing.

The work in partnerships also brings advantages that only can be measured in qualitative terms, with great exchange of experiences and learning in the co-creation projects, beyond displaying the problems of confidential information, patent sharing and limits of contribution, inherent of companies who work under a competitive capitalist model.

The study indicates that this incentive is necessary in this phase of companies' maturity, but the proper market might have a self-conduction, getting the benefits of the co-work in the future, even after a probable change of the regulation of investment in R\&D on the sector. For this, it is necessary that the benefits must be correctly measured and be part of the companies investment plan (customer and suppliers), what the study analyzes and indicates that does not occur currently.

\section{References}

ANP. (2011). Vendas pelas distribuidoras dos combustíveis derivados de petróleo. Agência Nacional do Petróleo. Superintendência de Planejamento e Pesquisa. Brasília, Brasil.

Canellas, A.L.S. (2007). Evolução da importância econômica da indústria de petróleo e gás natural no Brasil: contribuição a variáveis macroeconômicas. Rio de Janeiro, Brasil.

Creswell, J.W., \& Clark, V.L.P. (2007). Designing and conducting mixed methods research. Sage Publications. Thousand Oaks, California, USA.

Fischer, M.M., \& Varga, A. (2002). Technological innovation and interfirm cooperation: An exploratory analysis using survey data from manufacturing firms in the metropolitan region of Vienna. International Journal of Technology Management, 24(7-8), 724-742. http://dx.doi.org/10.1504/IJTM.2002.003080 
Freel, M.S., \& Harrison, R.T. (2006). Innovation and cooperation in the small firm sector: evidence from Northern Britain. Regional Studies, 40(4), 289-305. http://dx.doi.org/10.1080/00343400600725095

Furtado, A.T. (2003). Mudança institucional e inovação na indústria brasileira de petróleo. Colóquio Internacional "Energia, Reformas Institucionales y Desarrollo en America Latina", Universidad Nacional Autónoma de México, México D.F.

Ghemawat, P. (2007). A estratégia e o cenário dos negócios: texto e casos (2 ${ }^{\text {nd }}$ Ed). Porto Alegre: Bookman.

Hunger, D. (2002). Gestão estratégica: princípios e práticas. Prentice Hall, NJ, EUA.

Kaplan, R.S., \& Norton, D.P. (1992). The balanced scorecard - measures that drive performance. Harvard Business Review, January-February, 71-79.

Kaydos, W. (1991). Measuring, managing, and maximizing performance: what every manager needs to know about quality and productivity to make real improvements in performance. Productivity Press Inc.

Kim, W.C., \& Mauborgne, R. (2005). A estratégia do oceano azul: como criar novos mercados e tornar a concorrência irrelevante. $14^{\text {th }}$ edition. Elsevier, Rio de Janeiro, Brasil.

Kotler, P. (1994). Marketing management: analysis, planning, implementation and control. $8^{\text {th }}$ edition. Prentice Hall, Englewwod Cliffs, NJ, EUA.

Luecke, R. (2005). Harvard business essentials: managing creativity and innovation. Boston: Harvard Business School Press.

Neely, A. D. (1998). Measuring business performance: why, what and how. London. Economist Books Press.

Neely, A., Mills, J., Platts, K., Richards, H., Gregory, M., Bourne, M. et al. (2000) Performance measurement system design: developing and testing a process-based approach. International Journal of Operations \& Production Management, 20(10), 1119-1145. http://dx.doi.org/10.1108/01443570010343708

Nelson, R. (1992). National innovation systems, a comparative analysis. Oxford Universtiy Press, New York \& London.

Nudurupati, S.S., \& Bititci, U.S. (2000). Review of performance management information systems (PerforMIS), internal report. Centre for Strategic Manufacturing, DMEM, University of Strathclyde, UK.

Petrobras. Petróleo Brasileiro S.A. (2011). Investment plan 2011-2015. Rio de Janeiro, Brasil.

Porter, M. (1980). The competitive advantage of nations. Free Press, N.Y. USA.

Prahalad, C.K., \& Ramaswamy, V. (2004). O futuro da competição: como desenvolver diferenciais inovadores em parceria com os clientes. Rio de Janeiro: Elsevier Press. 
UNICAMP (2010). Inovação. Retrieved from: http://www.inovacao.unicamp.br/noticia.php? $\underline{i d=727}$, December $4^{\text {th }}$.

Journal of Industrial Engineering and Management, 2013 (www.jiem.org)

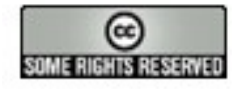

Article's contents are provided on a Attribution-Non Commercial 3.0 Creative commons license. Readers are allowed to copy, distribute and communicate article's contents, provided the author's and Journal of Industrial Engineering and Management's names are included. It must not be used for commercial purposes. To see the complete license contents, please visit http://creativecommons.org/licenses/by-nc/3.0/. 